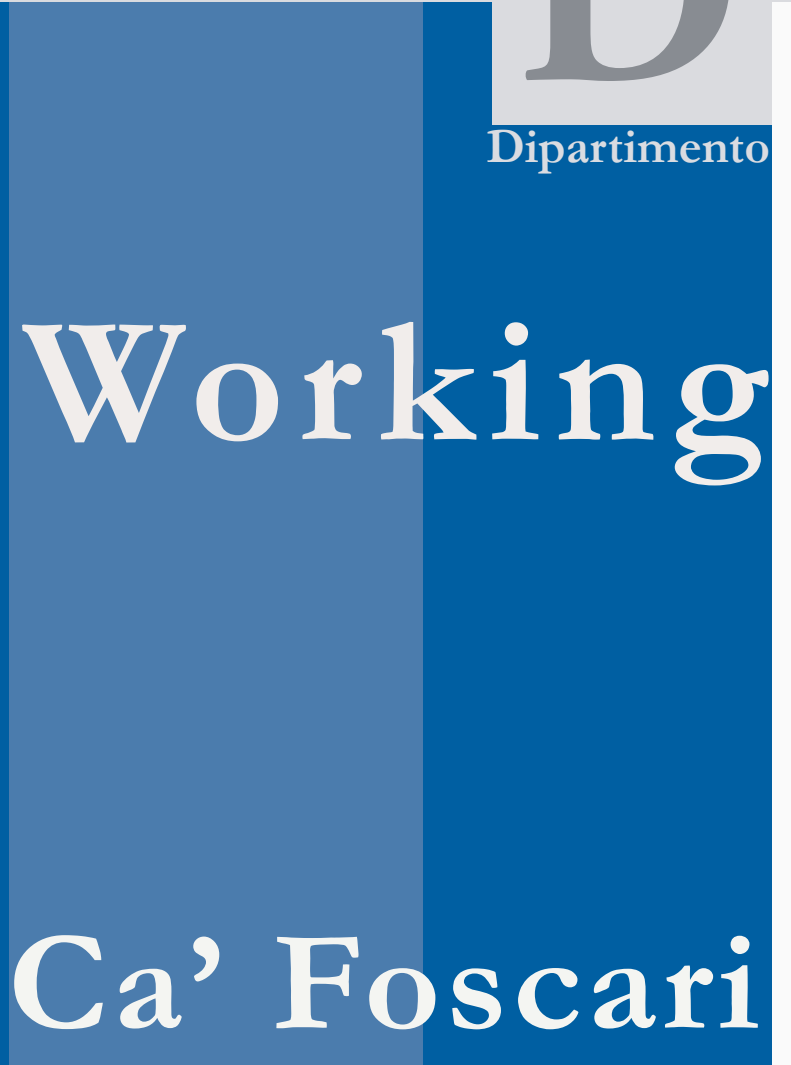

Scienze Economiche

Paper

Department

of Economics

University of

Venice

Giovanni Favero

Weather forecast or rain-dance?

On inter-war business barometers 


\title{
Weather forecast or rain-dance? On inter-war business barometers.
}

\author{
Giovanni Favero \\ Università Ca’ Foscari di Venezia
}

First Draft: September 2007

\begin{abstract}
In this paper, I use the materials of the debate on the reliability and the utility of "business barometers" of the Twenties in order to show that the theoretical reflexions of the time could be used by economic historians as a working hypothesis to analyze the influence exerted by circulating statistical data on the decisions of economic operators and institutions. I offer a short illustration of the origins and circulation of economic trends forecasting in the first decades of 20th century, paying particular attention to the critical attitude shown by Corrado Gini and Oskar Morgenstern and to the debate arisen inside the Harvard Committee for Economic Research on the inefficiency of its "index of economic conditions" during the 1929 crisis. I finally suggest that thorough research on the circulation and the influence exerted by the Harvard index on the business world, still after the slump in prices of New York Stock Exchange, could contribute to explain the behaviour of American businessmen and investors during the first Thirties, and the deepening of the crisis.
\end{abstract}

The paper was presented at the $11^{\text {th }}$ Annual Conference of the European Business History Association in Geneva, September 13-16, 2007.

\section{Keywords}

Economic forecasts, 1930s crisis, US.

\section{JEL Codes}

N22, N42, N82, B23

Address for correspondence: 


\section{Weather forecast or rain-dance? On inter-war business barometers.}

1. I present here the framework of a research, still far from being concluded, on the influence of statistical information on the choices of single and institutional operators. Focusing on the inter-war period, I use the so-called "business barometers" of the Twenties and the debate of the time on the effects of economic forecasting in order to draw some indications to interpret the mechanics of the crisis of the Thirties in the United States.

My intervention will be divided as follows: first, a short illustration of the origins and circulation of economic forecasting in the first decades of 20th century; second, an analysis of the international debate on business barometers, with particular attention to the critical attitude shown by Corrado Gini and Oskar Morgenstern in their writings; third, a detailed reconstruction of the debate on the failure of Harvard most-renowned barometer in forecasting the 1929 crash. Finally, I suggest a hypothesis on the role Harvard-inspired barometers played in pushing American businesses to take the wrong decisions during the first Thirties, so making the situation worse. 
2. In the first decades of the twentieth century statistical information on economic events opened up to a larger public of businessmen. This was mainly caused by the action of major operators. Besides the State, big corporations and banks were well acquainted with the advantages of a systematical examination of current events. Still, they preferred that also smaller operators were not too much unaware of market conditions, as to avoid sharp and unforeseeable shocks in the general course of business (Ayres 1924). So they thought it would be useful to spread the news gathered by their research departments by means of informatory circulars, in order to avoid market turbulence capable of threatening investment stability.

Later on, specialized agencies started gathering, processing and publishing data, putting services born inside private companies (but soon externalized) at the public's disposal. The first business indicators appeared in the United States before the war as an instrument to get speculative profits (Sauvy, 1948, 15). In short, it was a matter of meeting the business demand for statistically based forecasts (Armatte, 1992, 130-131).

Commercial forecasting agencies like the Brookmire Economic Service and the Babson Statistical Organization produced business barometers based on simple principles - that still did not seem trivial to their public. As we shall see later on, some scholars complained of such publications offering businessmen "nothing but the photograph of the forecasts they've just made, so that they take a line with their action" (Gini, 1930, 243). On the other hand, as Roger Babson himself (quoted in Armatte, 1992, 133) pointed out, 
barometers met a need for objective information which actors themselves, too concerned in their respective group strategies, cannot answer directly.

First business barometers were the result of complex elaborations, which still had the aim of offering simple and univocal interpretations of data, mainly by means of graphical representations incorporating the same interpretation. Only in the post-war period did more authoritative academic researchers start dealing with business cycle analysis, which seemed to be a most promising field of investigation in economic statistics. In 1919, the Committee for Economic Research of Harvard University began editing a business barometer, periodically published in the Review of economic statistics.

It is now worth explaining briefly how business barometers worked. The most famous ones were the above-mentioned Babson and Brookmire, as well as the Harvard forecasting system. The Babsonchart - published since 1910 - consisted of a “composite index” of United States economic activity, built up by weighting some "sensitive" indexes, and plotted as a broken line on a graph with time in abscissa and index values in ordinate. The resulting curve was interpolated by the "X-Y line”, “corresponding to the general business growth, to the increase of wealth in the considered period”. The "X-Y line” was built up in order that it roughly equalized areas included between it and the "composite index" curve. The forecasting mechanism of such a barometer originated from "Newton's action and reaction principle” or, in less bombastic words, from the assumption of approximate equivalence between the areas representing booms and the 
ones representing depressions. The Babson Statistical Organization kept the way the "X-Y line" was concretely built up secret for a long time. But Babson's forecast were actually also relying on relentless surveys of leading businessmen's opinions (Friedman, 2006, 12-13), this way working also as sort of an "index of the confidence" of investors.

The Brookmire Economic Service barometer was based on a completely different principle. Economic events were summarily classified into three groups: banking, speculation and business. Forecasts were based on the observation that most of the times "when banking starts a main variation (increase or decrease), stock prices will follow some months later and some more months later indicators of general business trends” (Vance, 1925, 79). It is clear that such a forecasting system involved the opinion, inspired by the works of Irving Fisher, that money and credit are the independent variable in business cycle (widely quoted in Brookmire, 1913). As it was based on the systematic examination of sequences between the trends of different indexes, Brookmire was an immediate precursor of the most sophisticated barometer built up by the Harvard Committee for Economic Research and published starting from January 1919.

The Harvard Committee director, Warren M. Persons, was convinced that existing barometers could be surpassed by means of a sharper distinction between gathering and publishing data, on the one hand, and analyzing and interpreting them, on the other. Therefore the Committee started manipulating published monthly economic data series, in order to correct them for seasonal variation and for the "secular (long-time) trend"; 
they then continued, charting each series as thus corrected in order to compare its fluctuations with others. Afterwards, the series were classified into groups according to the timing of their cyclical variations. Only at this point did they undertake the construction, out of the series included within any such group, of a composite series reflecting the average course of fluctuation for the group as a whole, and these "composite indexes" were superposed “upon a single chart” (Bullock-Crum, 1932, 132).

"No theory as to the interrelations of various aspects of the economic movement had been in mind when the investigation was undertaken". Nevertheless, "the results showed that (1) each of the three curves was associated with a particular type of economic activity"; "and (2) the relations of the three curves to each other at any given time appeared to afford a sound basis for forecasting”. This way, many years later, Bullock and Crum (1932, 132-133) claimed the empirical origin of the Harvard method, based on the sequentiality of curves A (speculation), B (business) and C (money and credit).

The order of the curves could give the wrong impression that changes in C (money conditions) were not important as a barometer of general business conditions, since they occurred after changes in B (business). As a matter of fact, the Harvard Committee used since 1920 both the A and the C curves in its forecasts of the B curve movements: in particular, "a decrease in A and a simultaneous increase in C” indicated the approaching crisis (BullockPersons-Crum, 1927, 77). As Persons (1930, 290) pointed out, this meant that the forecasts could be put in terms of causation as well as in terms of 
lag: money and credit availability (C) was actually the determining factor, influencing firstly the expectations of speculators (A) and then general business conditions (B). The actual sequence was hence C-A-B, where the relationship between $\mathrm{C}$ and the other curves was reversed.

3. The success of Harvard barometer derived mainly from its correct forecast of the timing of the 1920-1921 crisis, which unexpectedly hit the American economy. After this episode, a lot of businesses started using forecasts issued by Harvard, and by other private agencies. At the same time, the Federal Reserve System started its monetary interventions in order to regulate business trends: the not-so-good results of forecasting in 1923 were explicitly ascribed to the effects of Fed interventions, which modified the sequence of the curves.

Ironically, the influence of the Harvard barometer on business grew wider as its forecasting mechanism started jamming. The 1921 success gave the Harvard "business conditions index" a national- and international-wide renown. The methods in use by the Committee for Economic Research for the statistical depuration of series and for measuring the correlation between different series were adopted by commercial forecasting agencies, sometimes with naivety and sometimes with following polemics on their right use (see Karsten, 1926; Bullock-Persons-Crum, 1927). The same forecasting methods were also adopted by some big businesses in order to plan their orders and investments: American Telegraphs and Telephones used the Harvard methodology to build up a barometer on its own, and 
General Motors usually confronted Harvard forecasting with its own sales estimations (Richardson, 1929, 184-189).

Born as agile business reports, during the Twenties barometers rose to scientific respectability. At the end of the decade, central banks and governments based their interventions on this kind of data. Barometers were no longer a simple way of rationalizing individual behavior on the market; they had become the empirical basis of a policy devoted to institutional regulation of the market itself. As such, they went parallel with the establishment of big offices and workshops which, by means of a wide and careful collection of data and news on economic life trends, could with certainty point out approaching crises: many institutes and publications taking as their model the Harvard Committee and its "business conditions index" were founded in the European countries during the Twenties.

In the United Kingdom, the London and Cambridge Economic Service was established under the direction of William Beveridge in 1921. In France, the Statistical Institute of Paris University was set up in the same year by Lucien March. Institutes for economic trends forecast were established in those years also in Vienna, where Hayek and then Morgenstern were appointed as directors, in Moscow, under the direction of Kondratieff, and in Berlin, where Ernst Wagemann (1930) developed a much more detailed system of indexes (Morgan, 1990, 66; Deblock 2000). In some cases, caution prevailed. The Swedish Ministry of Commerce published a barometer modeled on the Harvard one, but being afraid of exaggerated expectations of the industrial world, suspended publication and 
resumed it only after drawing the cautions required for its interpretation to the attention of the public. In Italy, the Universities of Padua and Rome started publishing the "Indici del movimento economico italiano", still excluding any forecasting concerns, in view of the doubts expressed on the matter by the president of the publishing committee, Corrado Gini (1926): Gini (1930, 245) defined the indexes compiled by the Italian committee as a “rain gauge” with respect to forecasting "barometers".

In 1926, the institution of a Committee of experts on business barometers on the initiative of the League of Nations was a sign of the increasing importance attributed to business cycle analysis. Such a committee was established considering that "a better evaluation of all data concerning economic factors" should be "useful in steering credit policy, so to partially soften the extreme fluctuations of economic activity, which is harmful to investment steadiness” (Gini, 1926, 4). Persons (1930, 307) himself, speaking at the Warsaw meeting of the International Statistical Institute in August 19291, put the steady prosperity of the Twenties in the United States down to the greater knowledge of the current facts of business, but also to the growing experience of the Fed in utilizing this knowledge in monetary policy. Thus, the forecasting work of the Harvard Committee and other agencies found its operating effect in the stabilization policy that the Fed carried out in the same years.

It's worth to say that some criticism on this optimistic view did emerge since the Twenties: I will focus here on Corrado Gini's and Oskar Morgenstern's writings on this matter. 
Gini $(1926,4)$ started from the above-mentioned meeting of the Committee of experts on business barometers in December 1926, which he attended, to "examine some problems raised during the discussions that took place there or were born in [his] mind following on these ones”.

Taking a remark of Pantaleoni (1924, 347), Gini began by considering the eponymous metaphor of new statistical devices (used for the first time in De Foville, 1888): "between business barometers and meteorological ones there lies an essential difference: the reports of meteorological barometers do not exert - of course - any influence on what will be the weather like, whereas the reports of business barometers can influence considerably business trends”.

According to this observation, at the beginning he admitted the validity of the point of view of the League of Nations, connecting an improvement in the economic forecasts to an increase in the credit policy effectiveness. It was reasonably likely that the lag between discount rate movements and business fluctuations would be reduced because of more widespread and ready knowledge of those fluctuations. But this kind of relationship was more general: "the widespread knowledge of economic indexes tends to go through, and at any rate makes shorter, the lapse of time between related movements of several economic variables”. Therefore, where interdependence exists between two variables, "the reaction of the belated variable on the earlier one" will be "ahead of time because of this knowledge". Still, only if "this reaction, as it is the case of the business fluctuations and the discount rate, is fulfilled as a compensation”, will the 
effect be that of "mitigating fluctuations of earlier variable". Should that not be the case - as, in his opinion (Gini, 1926, 14-15), it happened most of the times (in the relationship between prices and wages, or between domestic and external prices) - "the belated variable tends with its variations to react on the earlier variable, which determines it, making its variations more marked", this way triggering off, instead of a regulation mechanism, "a vicious circle”.

To sum up, Gini wished for a development of money and credit control as an instrument to mitigate economic fluctuations, but was persuaded that a wider circulation of economic information would have pro-cyclical and, at worst, destabilizing effects. It is interesting to see the consonance between this argument and the criticism by Oskar Morgenstern (1928, summarized in Marget, 1929) on the circulation of economic forecasts.

Morgenstern started by denying any possibility of applying the theory of probability to economics, given the lack of homogeneity and statistical independence of economic data. In his opinion, the Harvard Committee was not applying the statistical theory of probability to its data, but a "semiological" theory of causes, which could be falsified. This “experiment” could be very useful in order to foster the development of economic theory, allowing it to test the causal connections it was supposing. But when its results were circulated to the public and found practical use in steering entrepreneurial choices and institutional economic policy, they could have destabilizing effects. In fact, a widespread reliance on economic 
forecasts endangered the "rationality" of economic processes by modifying entrepreneurs' “reference points”.

Morgenstern concluded pointing out the need to separate the scientific research on business trends from the sale of a forecasting service to the public, but also from its use for monetary policy. Interestingly, it was starting from his 1928 analysis of the conditions and possibilities of economic forecast that Morgenstern developed his considerations on the "perfect forecasting" problem. The same idea that "the calculation of the effects of our choices is always based on the expected choices of the others" was at the origin of his first contributions on game theory (von Neumann Morgenstern, 1944).

This opens an attractive path of research in the history of economic thought, which is not the case to follow here. Also from the point of view of the history of economic thought, the literature has already shown how following developments in economic science brought this empirical approach to the study of business cycles, so strong in the Twenties, to lose its dominant role in the Thirties. For instance, it would be possible to make reference to Udny Yule (1926) radical criticism of statistical correlations between time-series, or to the concurrent "development of the alternative quantitative programme in econometrics” (Morgan, 1990, 67). But let's go back to the story of the Harvard barometer, and then to economic history.

4. Only two months after the extensive discussion which the International Statistical Institute devoted to economic forecasts in 1929, the 
Wall Street crack - unforeseen and undervalued by the Harvard Committee - gave a great blow to economic statistics forecasting ambitions. In the Thirties business barometers (which went on forecasting a rapid recovery) were made commercially useless by the Great Depression. In 1935 the Harvard Index stopped coming out, and the Harvard Economic Society shut down the Committee on Economic Research. Other barometers passed away in the same years.

Why the forecasting performance of the Harvard barometer was so poor in this occasion? Joseph Schumpeter (1954, 1165) is one of the historians who assert that Persons and his team were only too aware of the risk of a distorted or mechanical reading of the forecasts circulating in the "Weekly Report" of the "Review of Economic Statistics". Was it this very awareness that made Harvard statisticians so careful that they "either would not believe their own methods or else would not take what they believed to be a serious responsibility in predicting depression” in 1929? Did Persons and his colleagues at the Harvard Committee for Economic Research decline the responsibility of forecasting the crash?

The Committee itself had a different version, if we rely on an article explicitly accounting for the interpretation and performance of the Index. Bullock and Crum $(1932,138)$ relate that, "during the short post-war cycle that ended in the depression of 1921, the performance of our Index” performed 
very well. Still, after 1922 the situation became more complicated as, "with the gradual return of prosperity, the federal reserve authorities were free for the first time to develop credit policies suited to normal times”. The steps the Fed and the Department of Commerce took in those years to deal with the economic trend "introduced a new factor which seemed to make it absolutely necessary to supplement our index chart by independent study" (Bullock and Crum, 1932, 139).

That was why the Committee preferred to take a careful attitude when, in the summer of 1928, the relative positions of the $\mathrm{A}$ and $\mathrm{C}$ curves seemed to point to "the approach of a cyclical decline into depression”. The prevailing opinion was that the $A, B$ and $C$ curves were not to be read mechanically, and in fact "the avoidance of a mechanical reading proved correct during the next eight or nine months". So, when "the chart gave a new and much more emphatic warning" in the spring of 1929, this once again went unheeded. And yet, "if followed mechanically, the chart would have given a satisfactory forecast even of the extraordinary developments late in 1929”.

What was then that drove the Harvard statisticians to underrate their own index indications so stubbornly? Following the account of Bullock and Crum, it would be essentially the 
lack of an analysis of the international situation, which concealed "the unfavorable effects which high money rates in this country" were producing in Europe and elsewhere (Bullock and Crum, 1932, 142). For such a development the Committee should have been prepared. Still, having "seen the intervention of the federal reserve authorities prove effective in averting serious situations in the fall of 1927 and the fall of 1928”, it “counted upon similar action in 1929 if, as seemed likely, it should become necessary”.

Hence, it would be the confidence in the effectiveness of Fed intervention that would drive the Harvard Committee to underestimate the first repeated signs of the crisis that its own barometer showed. The attempt to blame the overconfidence on monetary authorities has been defined "very clumsy" by Christian Deblock (2000, 375). Still, the Committee's selfcriticism of the limits of an analysis focused only on the American economy agrees with the results of present historical research on the 1929 crash (Eichengreen 1992), which blames the same limits in the attitude of the Fed.

In August 1929, in the above-mentioned paper presented at the International Statistical Institute meeting, Persons (1930, 293) himself had noticed the danger deriving from a difficulty of credit control. In 1928, the absorption of credit for speculative purposes forced the Federal Reserve System 
to follow a vacillating money policy; this behavior led in 1929 to an apparent "loss of control of the money market by the federal reserve banks".

From this point of view, Persons' version of the facts is different from Bullock and Crum's: the Harvard Committee was not relying so blindly on the deus ex machina of Fed intervention. The problem was another: antislump interventions carried out in the previous decade had apparently altered "the time sequence, which had previously been observed between the cyclical fluctuations of speculation, business and money rates”.

In the following session of the ISI in 1930, Persons (1931, 487-488) was in his turn blaming the Fed intervention, but as "largely responsible for the change in relationships which we have described" between the curves. Since 1922, the intervals between the cyclical movements of the curves considerably shortened. In 1929, the movements of speculation (A) were even responding to, rather than preceding business (B), and the interest rate (C) was moving together with $\mathrm{A}$ and $\mathrm{B}$, rather than following some months later. The Harvard Committee's forecasting choices in 1929 were hence based mainly on the awareness that the sequences were no more working, and on the consequent loss of confidence in its own forecasting mechanism: in 
Schumpeter words, in this situation the responsibility of forecasting the crash was really too heavy.

5. The choice to focus in this paper on the case of the Harvard barometer should not be interpreted as a dismissal of the importance of other barometers and forecasting services in general. The main rival of Persons' Committee was Irving Fisher's Index Number Institute based in New Haven, CT, publishing the “Irving Fisher's Business Page” on diferrent newspapers. Fisher's forecasts were based on the presupposition that the determining variables in business fluctuations were entirely monetary, and could be measured by means of the quantity of circulating money and checking deposits. When the quantity of money rose, prices increased and, nominal interest rates being slow to respond, real interest rates fell: in this situation, businesses were pushed to invest excessively and, when interest rates finally rose, could not pay back their debts. At this point, banks restricted the credit, reducing the circulating quantity of money and pushing prices down (Friedman, 2006, 15-16).

It is evident that also Fisher's forecasting theory was jammed by the Federal Reserve antislump interventions on interest rates. Actually, both Harvard and Fisher missed the crash and remained optimist long after it. An econometric 
analysis based on the same data of Harvard and Fisher and using modern time-series methods shows that the crash and the following Depression were actually not forecastable (Dominguez-Fair-Shapiro, 1988).

Still, this does not mean that barometers had no effect on entrepreneurial choices. Making reference to Gini and Morgenstern's critical remarks on the circulation of economic forecasting, it seems possible to argue that they could have partially modified entrepreneurs' “points of orientation”. A first hypotesis I present here, still to be verified on sources, concerns what happened in the first years following the 1929 crash. Actually, as a warning to the reader, it would be useful to say that the following last section of this paper is just a research project and not the result of exhaustive research.

Following the optimism of forecasters on a huge recovery, some still-sound businesses could have been pushed to invest on credit, given the low relative prices of investment goods and the decrease in interest rates which followed the crash and went on until 1931. Their attempt to exploit a supposed temporary downturn would fail dramatically. The decrease of the money stock which followed the 1931 Fed decision to rise interest rates (Friedman-Schwarz, 1963), the permanent decline in aggregate demand (Temin, 1976), the collapse of commodity prices (Kindleberger, 1986) were all 
working against the recovery. The consequence would be a further deepening of the Depression, caused by the bankrupt of most of surviving businesses, falling on the 1933 bank crisis.

The economic and historical literature on the investment trend during the Depression (Steindl, 1951; Bernstein, 1987) offers a lot of data useful to verify the compatibility of this hypothesis with the general economic trend. Business case studies on major companies allow, on the other hand, checking the timing of investment choices of single businesses and their sources of information. The successful use of sales reports by the General Motors Co. (Kuhn, 1986) or the introduction of internal comptrollers at Sears, Roebuck \& Co. (Emmet-Jeuck, 1950) suggest that when businesses were able to collect and use the information that was really concerning them, they could react to the crisis. Still, this is a matter of very big businesses: smaller companies were relying on market information and probably on general forecasts.

It would then be interesting to know exactly which firms were subscribers receiving the "Weekly Report" of the Harvard Committee, and to know if they were using it in their decision-making process.

The papers of the Harvard Committee are deposited at the Becker Library, and include (according to the website): 1) forms, data, newspapers and journals used as sources for the elaboration of forecasts; 2) minutes of the periodical meetings of the Committee, offering details of forecasting 
choises; 3) drafts of the "Weekly Report" and of "Review of Economics and Statistics”, useful for an analysis of publication choices, with a list of subscribers; 4) the correspondence with other institutes, scholars, businessmen, entrepreneurs and readers, allowing to check the circulation and the debate on the barometer.

Starting from this material, it would be possible not only to get to the bottom of the different versions of the unforecasted 1929 crash given by Persons, and Bullock and Crum, but also have a measure of the circulation of barometers in the business environment, and a list of the businesses directly using the Committee Report. A second step of the research could be to check the archives of these businesses, where existing, in order to find documentation of the correspondence with the Harvard Committee and eventual traces of the use of its forecasts in minutes of board meetings and balance-sheet reports.

\section{References:}

M. Armatte, "Conjonctions, conjoncture et conjecture: les baromètres économiques (18851930)", Histoire et mesure, 7/ 1-2, 1992, pp. 99-149.

L.P. Ayres, "How a big bank plans its investments”, American Bankers' Association Journal, 1924/8.

M. Bernstein, The Great Depression: delayed recovery and economic change in America, 1929-1939, Cambridge: Cambridge University Press 1987.

C.J. Bullock, W.L. Crum, “The Harvard index of economic conditions: interpretation and performance, 1919-31”, Review of Economic Statistics, 14, 1932, pp. 132-148. 
C.J. Bullock, W.M. Persons, W.L. Crum, “The construction and interpretation of the Harvard Index of business conditions”, Review of Economic Statistics, 9, 1927, pp. 74-92.

A. De Foville, “Essai de météorologie économique”, Bulletin de l’Institut International de Statistique, 1888.

C. Deblock, "Le cycle des affaires et la prévision économique: les instituts de conjoncture et la méthode des «baromètres» dans l'entre-deux-guerres”, in J.-P. Beaud, J.-G. Prévost (eds.), The age of numbers: statistical systems and national traditions, Sainte-Foy, QU: Presses de l’Université de Québec 2000, pp. 357-410.

K.M. Dominguez, R.C. Fair, M.D. Shapiro, "Forecasting the Depression: Harvard versus Yale”, The American Economic Review, 78/4, 1988, pp. 595-612.

B. Eichengreen, Golden fetters: the gold standard and the Great Depression, 1919-1939, New York: Oxford University Press 1992.

B. Emmet, J.E. Jeuck, Catalogues and counters: a history of Sears, Roebuck and Company, Chicago, IL: The University of Chicago Press 1950.

M. Friedman, A.J. Schwarz, A monetary history of the United States, 1867-1960, Princeton, NJ: Princeton University Press 1963.

W. Friedman, The rise of business forecasting in the United States, draft paper presented for the EBHA 2006 meeting, July 21, 2006.

C. Gini, "La riunione del Comitato di esperti per la questione dei barometri economici indetta dalla Soc. delle Nazioni”, Indici del movimento economico italiano, I, 1/4, 1926.

C. Gini, "La crisi mondiale", L'Information, 32/202, September 5, 1930.

C.P. Kindleberger, The world in depression, 1929-1939, Berkeley, CA: University of California Press, 1986 (revised edition).

Kuhn, GM passes Ford, 1918-1938: designing the General Motors performance control, Pittsburg, PA: Pennsylvania State University 1986.

A.W. Marget, "Morgenstern on the methodology of economic forecasting”, The Journal of Political Economy, 37/3, 1929, pp. 312-339. 
M.S. Morgan, The history of econometric ideas, Cambridge: Cambridge University Press 1990.

O. Morgenstern, Wirtschaftsprognose: Eine Untersuchung ihrer Vorausseetzungen und Möglichkeiten (Economic forecast: an analysis of its conditions and possibilities), Vienna: Springer 1928.

J. von Neumann, O. Morgenstern, Theory of games and economic behavior, Princeton, NJ, Princeton University Press, 1944.

M. Pantaleoni, “La crisi del 1905-1907”, Annali di economia, 1, 1924, pp. 300-542.

W.M. Persons, “L’étude des éléments statistics les plus instructifs en vue des prévisions économiques à rassembler dans les principaux pays”, Bulletin de l'Institut International de Statistique, 24/2, 1929, pp. 283-318 (in English).

W.M. Persons, “The recession of 1929-1930 in the United States”, Bulletin de l'Institut International de Statistique, 25/3, 1930, pp. 479-489.

J.H. Richardson, "Business forecasting in the United States: recent developments by individual companies”, International Labour Review, 19/2, 1929, pp. 175-192.

A. Sauvy, La prévision économique, Paris: PUF 1948 ( $2^{\text {nd }}$ ed.).

J.A. Schumpeter, History of economic analysis, New York: Oxford University Press 1954.

P. Temin, Did monetary forces cause the Great Depression?, New York: Norton 1976.

R. Vance, Business and investment forecasting: forecasting methods and their practical application, New York-London: Harper and brothers publishers 1925 ( $2^{\text {nd }}$ ed.).

E. Wagemann, Economic rythm, New York: McGraw-Hill 1930.

U. Yule, "Why do we sometimes get non-sense correlations between time-series? A study in sampling and the nature of time-series”, Journal of the Royal Statistical Society, 89, 1926, pp. 1-64. 